\title{
Exogenously Applied Nitrogen and Zinc Fertilizers Improved the Rice Productivity
}

\author{
Muhammad Arif ${ }^{1}$, Muhammad Zahid ${ }^{1}$, Muhammad Tasneem ${ }^{1}$, Fiaz Bashir ${ }^{1}$, Muhammad Shafiq ${ }^{1}$, Naeem Akhtar $^{1}$, \\ Ghulam Yaseen ${ }^{1}$, Adeel Anwar ${ }^{2}$ and Iqra Tariq ${ }^{3}$
}

${ }^{1}$ Directorate of Land Reclamation, Irrigation Department of Punjab, Pakistan

${ }^{2}$ Pir Mehr Ali Shah, Arid Agriculture University Rawalpindi, Pakistan

${ }^{3}$ Muhammad Nawaz Sharif University of Agriculture Multan, Pakistan

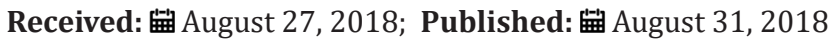

*Corresponding author: Muhammad Arif, Directorate of Land Reclamation, Irrigation Department of Punjab, Pakistan

\begin{abstract}
Nutritious management in fine rice is primarily concomitant with the application of nitrogen and zinc fertilizers, which is challenging to amend under field conditions due to variations in soil fertility and environmental conditions. Therefore, a field experiment was carried out at Chakkanwali reclamation Research Station district Gujranwala to explore the role of nitrogen and zinc on the growth and yield of fine rice during kharif 2016. This study was laid out in a randomized complete block design with factorial arrangement having three repeats. Experimental treatments comprised of $2 \%$ foliar spray of nitrogen and zinc at tillering, booting, and flowering stage alone and in combinations. Results indicated that exogenous application of $2 \%$ nitrogen and zinc at flowering stage significantly improved all the yield contributing parameters which ultimately enhanced the final paddy yield.
\end{abstract}

\section{Introduction}

Rice is a delicious food for all the tiers of society in most of the states around the world. Billions of people eat rice for at least once a day to fulfill their dietary needs [1]. Increasing rice productivity in all domains is authoritative to meet the mounting demand of the world's population. Rice grains are wonderful source of carbohydrates, fiber, fat, vitamins, minerals, energy and number of its by-products increases the value of rice crop across the biosphere [2-4]. Rice accounts for $3.1 \%$ in the value added in agriculture and 0.6 percent of GDP of Pakistan [5]. Rice cultivated area in Pakistan increased up to $6.4 \%$ as compared to last year during 2017-18. Its cultivation grasped historically maximum level of 7,442 thousand tones against the production of 6,849 thousand tones [5]. Average production in Pakistan is lower as compared to developed countries of the world. Among various factors causing turn down the rice productivity; imbalanced use of fertilizers is significant [6].

Optimum plant nourishment is one of the absolute imperative elements in enhancing the rice productivity. Among all the plant nutrients, nitrogen is critical for rice, and generally it is the most yield limiting nutrient in rice production domains around the globe [7]. As availability of organic nitrogen in soil is frequently

minimizing by intensive cultivation of exhaustive crops, leaching, ammonia vitalization and de-nitrification. Rice plants required nitrogen during early growth phase to encourage tillering and vegetative growth, which in turn regulates the probable number of panicles. While application of nitrogen during reproductive phase improved the primary panicle formation and contributes to sink size in the late panicle formation period and play a vital role in grain filling, enhancing the photo-synthetic capacity and encouraging accumulation of carbohydrate in leaf sheaths and culms [8]. Among various micronutrients, zinc also play vital in optimum crop growth [9] and is prerequisite in small amount to allow several crucial plant physiological pathways to work properly [10]. It plays an important role in maintaining the integrity of biological membranes, the resistance to contagion by assured pests [11] and the pollination by affecting the formation of pollen tube $[12,13]$. It is also necessary in the carbonic enzymes that benevolences in all photosynthetic tissues and for chlorophyll biosynthesis $[14,15]$.

However, its scarcity upsets numerous biochemical processes, such as auxin metabolism, enzyme activation, cytochrome and nucleotide synthesis, chlorophyll production, membrane integrity 
and growth [16]. Its insufficiency shows uneven plant growth, dusty brown spots on upper leaves of stunted plants, reduced tillering and enhanced spikelet sterility in rice Dobberman and Fairhurst, 2000. Application of nitrogen fertilizer directly to soil causes loss in the form of volatilization and leaching while in case of zinc fertilizers, the soluble portion leaches down. These losses can be minimized through the exogenous application of these nutrients which may confirm prompt accessibility of nutrients by the leaf tissues and effective movement to the developing parts of plant with minimum loss [17-21]. Keeping in mind these facts, the present study was designed to explore the role of exogenous application of nitrogen and zinc fertilizers at different stages of rice.

\section{Materials and Methods}

\section{Experimental site and treatments}

A field study was carried out at Chakkanwali Reclamation Research Station, District Gujranwala to explore the response of exogenous application of nitrogen and zinc on different growth stages of fine rice during Kharif 2016. The experiment was laid out in a randomized complete block design with factorial arrangement having three repeats. Experimental treatments comprised of $2 \%$ foliar spray of $\mathrm{N}$ and $\mathrm{Zn}$ at tillering, booting and flowering stage alone and in combinations.

\section{Soil analysis}

Prior to seedbed preparation, composite soil samples were collected from 0 to $30 \mathrm{~cm}$ depth for physico-chemical analysis. The soil of experimental site was silt loam, having pH 8.5, EC $2.11 \mathrm{dS}$ $\mathrm{m}^{-1}$, organic matter $0.56 \%$, total nitrogen, available phosphorus and exchangeable potassium $0.042 \%, 0.0062,0.136 \mathrm{mg} \mathrm{kg}^{-1}$.

\section{Crop husbandry}

Twenty-eight days old nursery of fine rice (cv. Super Basmati) was transplanted in standing water on $11^{\text {th }}$ July 2016 with $20 \mathrm{~cm}$ plant to plant and $22.5 \mathrm{~cm}$ row to row distance. Recommended dose of phosphorus (90 kg ha-1) and $1 / 3^{\text {rd }}$ of nitrogen (50 kg ha-1) was applied at the time of transplantation. The remaining two-thirds of inorganic nitrogen (100 kg ha-1) were applied in two equal splits at tillering and panicle initiation stages. The water level in the field was maintained at 15 to $20 \mathrm{~cm}$ up to 30 days after transplanting and then water was drained out from the field for 2 days. After that water level was maintained at 10 to $15 \mathrm{~cm}$ until a week before final harvest. All other agronomic practices were kept uniform for all the experimental units to keep the crop free from pests. A unit area $\left(1 \mathrm{~m}^{2}\right)$ was selected at random from two different sites for each plot. At maturity, grain yield, biological yield, harvest index, plant height, panicle length, number of kernels per panicle, number of tillers per plant and final plant height was measured.

\section{Statistical analyses}

The data for investigated treatments was analyzed by using the software Statistix 8.1, following Fisher's analysis of variance and the least significant difference (LSD) test at 5\% levels of probability was used to compare the means of different treatments [22].

\section{Results and Discussion}

\section{Plant height (cm)}

Plant height divulges the overall vegetative growth of rice in response to management practices. The results showed that the foliar application of nitrogen and zinc at different growth stages had non-significant effect on final plant height (Table 1). However exogenous application of $2 \%$ nitrogen and zinc at booting stage produced taller plants $(129.08 \mathrm{~cm})$. While foliar spray of $2 \%$ zinc at booting produced minimum plant height $(114.60 \mathrm{~cm})$ of rice.

\section{No. of fertile tillers per plant}

Tillering of a plant depends on the genotype, environment as well as the plant nutrition. Statistical analysis of the data showed significant effect of foliar spray of $2 \%$ nitrogen and zinc at different growth stages of rice (Table 1). Exogenous application of $2 \% \mathrm{~N}+\mathrm{Zn}$ at tillering stage produced significantly higher number of tillers per plant (21.28). Lower number of fertile tillers per plant (14.03) was observed with foliar spray of $2 \% \mathrm{~N}+\mathrm{Zn}$ at booting stage. Higher number of fertile tillers per plant might be due to the application of $\mathrm{Zn}$ that increased $\mathrm{N}$ use efficiency that ultimately produced more effective tillers per plant. Similar findings were reported by Islam [23] and Abdul and Balasubramanian [24]. Similarly, the studies carried out in IRRI [16] indicated that zinc application activates and increases tillering capacity in rice due to improved enzymatic activity.

\section{Panicle length (cm)}

Panicle length affects in grain yield by more transport of photosynthesis material. Panicle length varied significantly due to exogenous application of $2 \%$ nitrogen and zinc at different growth stages (Table 1). Foliar application of $2 \% \mathrm{~N}+\mathrm{Zn}$ at flowering stage produced significantly higher panicle length $(21.85 \mathrm{~cm})$. While foliar application of $2 \% \mathrm{Zn}$ at tillering stage produced minimum panicle length $(16.55 \mathrm{~cm})$. Similar results were reported by Bandara [25] who showed that panicle length of rice was affected by nitrogen and zinc application. Similarly, Sarwar [26] also observed the low size of panicle length in without $\mathrm{Zn}$ application.

\section{No. of kernels per panicle}

Many factors affect the kernels per panicle such as genotype, cultural practices used (planting date, seeding rate and soil fertility) and growing conditions (air and soil temperature, etc.). Exogenous application of $2 \%$ nitrogen and zinc at different growth stages had no significant effect on number of kernels per panicle (Table 1). However, foliar spray of $2 \% \mathrm{~N}+\mathrm{Zn}$ at flowering stage produced higher number of kernels per panicle (126.33). While foliar application of $2 \% \mathrm{Zn}$ at tillering stage lower number of kernels per panicle (114.05). 
Table 1: Effect of exogenous application of nitrogen and zinc on the growth and yield contributing parameters.

\begin{tabular}{|c|c|c|c|c|}
\hline Treatments & Plant height (cm) & No. of tillers per plant & Panicle length (cm) & No. of kernels \\
\hline $\begin{array}{c}\text { 2\% foliar spray of N at } \\
\text { tillering }\end{array}$ & 119.17 & $20.540 \mathrm{a}$ & $17.067 \mathrm{~b}$ & 117.1 \\
\hline $\begin{array}{c}2 \% \text { foliar spray of N at } \\
\text { booting }\end{array}$ & 123.42 & $15.040 \mathrm{bc}$ & 122.38 \\
\hline $\begin{array}{c}2 \% \text { foliar spray of N at } \\
\text { flowering }\end{array}$ & 124.33 & $16.113 \mathrm{bc}$ & $18.650 \mathrm{ab}$ & 114.05 \\
\hline $\begin{array}{c}2 \% \text { foliar spray of Zn at } \\
\text { tillering }\end{array}$ & 116.09 & $18.233 \mathrm{ab}$ & $16.55 \mathrm{~b}$ & 118.14 \\
\hline $\begin{array}{c}2 \% \text { foliar spray of Zn at } \\
\text { booting }\end{array}$ & 114.6 & $15.250 \mathrm{bc}$ & $17.760 \mathrm{~b}$ & 119.66 \\
\hline $\begin{array}{c}2 \% \text { foliar spray of Zn at } \\
\text { flowering }\end{array}$ & 116.97 & $14.630 \mathrm{c}$ & $18.013 \mathrm{~b}$ & 119.96 \\
\hline $\begin{array}{c}2 \% \text { foliar spray of N+ Zn at } \\
\text { tillering }\end{array}$ & 121.53 & $21.283 \mathrm{a}$ & $20.047 \mathrm{ab}$ & 125.22 \\
\hline $\begin{array}{c}2 \% \text { foliar spray of N+ Zn at } \\
\text { booting }\end{array}$ & 129.08 & $14.033 \mathrm{c}$ & $21.85 \mathrm{ab}$ & 126.33 \\
\hline $\begin{array}{c}2 \% \text { foliar spray of N+ Zn at } \\
\text { flowering }\end{array}$ & 128.83 & $15.873 \mathrm{bc}$ & 3.7637 & $\mathrm{~N}$ \\
\hline LSD 0.05p & N.S & 3.4705 & \\
\hline
\end{tabular}

\section{No. of panicles per hill}

Number of panicles per hill plays an imperative role in influencing the final grain yield. Genetic makeup, optimum crop management and availability of nutrients is greatly influenced the setting of panicles. Statistical analysis of the data showed significant effect of foliar spray of $2 \%$ nitrogen and zinc at different growth stages number of panicles per hill of rice (Table 2). Exogenous application of $2 \%$ nitrogen at flowering stage produced significantly higher number of panicles per hill (7.66). Lower number of panicles per hill (6.81) was observed with foliar spray of $2 \%$ zinc at tillering stage. It could be attributed to the improved availability and uptake of other nutrients resulting in improvement in metabolic activities.

\section{Thousand kernel weight (g)}

Thousand kernel weight varied significantly due to exogenous application of $2 \%$ nitrogen and zinc at different growth stages (Table 2). Exogenous application of $2 \%$ nitrogen and zinc at flowering stage produced significantly heaver kernel weight (20.09 g). While foliar spray of $2 \%$ zinc at tillering stage produced minimum kernel weight (18.09 g). It might be due to more efficient participation of all three micronutrients in various metabolic processes which enhanced accumulation of assimilates in the grains and resulted in heavier grains. Our results are supported by Suleimani [27] who recorded significantly increased kernel weight by integrating micronutrients like $\mathrm{Zn}, \mathrm{Fe}, \mathrm{Mn}$ and $\mathrm{Cu}$.

\section{Biological yield ( $\mathrm{t} \mathrm{ha}^{-1}$ )}

Vegetative and reproductive growth of rice crop indicated the biological yield and it displays an indirect index of photosynthetic machinery as it represents the total biomass assembles by the plant. Biological yield varied significantly due to exogenous application of $2 \%$ nitrogen and zinc at different growth stages (Table 2). Foliar spray of $2 \%$ nitrogen and zinc at flowering stage produced maximum biological yield (10.12 $\left.\mathrm{t} \mathrm{ha}^{-1}\right)$. While application of $2 \%$ zinc at booting stage produced minimum biological yield (9.15 tha $\left.{ }^{1}\right)$. Supreme biological yield was recorded may be owing to more plant height, fertile tillers per plant, number of kernels per panicle and thousand grain weight with efficient utilization of nutrients, sunlight interception and water, which ultimately produced more biomass and grains [28].

\section{Paddy yield ( $\left.\mathrm{t} \mathrm{ha}^{-1}\right)$}

Paddy yield is composed of various yield components such as number of panicles, kernels per panicle and1000 kernel weight. Statistical analysis of the data showed significant effect of foliar spray of $2 \%$ nitrogen and zinc at different growth stages on paddy yield of rice (Table 2). Exogenous application of $2 \%$ nitrogen and zinc at flowering stage produced significantly higher paddy yield (3.82 $\mathrm{t} \mathrm{ha}^{-1}$ ). Lower paddy yield (3.32 $\mathrm{t} \mathrm{ha}^{-1}$ ) was observed with foliar spray of $2 \%$ zinc at booting stage. In this study, the use of nitrogen and zinc produced the highest paddy yield due to the combined effect of many yield components including higher number of tillers per plant, number of panicles per hill, number of kernels per panicle and 1000 kernel weight. Chaphale [29] recorded higher paddy yield when NPK was applied with zinc in combination. Previous findings also revealed that the application of zinc fertilizer not only increased yield but also zinc concentrations in rice seed [30-33].

\section{Harvest index (\%)}

Harvest index indicated the photosynthesis efficiency of crop plants which converted into the economic yield. More harvest 
index showed the prolific efficiency of a crop. Harvest index varied significantly due to exogenous application of $2 \%$ nitrogen and zinc at different growth stages (Table 2). Maximum harvest index $(37.79 \%)$ was recorded with the exogenous application of

Table 2: Effect of exogenous application of nitrogen and zinc on yield contributing and yield parameters of rice.

\begin{tabular}{|c|c|c|c|c|c|}
\hline Treatments & $\begin{array}{c}\text { No. of panicles per } \\
\text { hill }\end{array}$ & $\begin{array}{l}1000 \text { kernel weight } \\
\text { (g) }\end{array}$ & $\begin{array}{l}\text { Biological yield (t } \\
\text { ha }^{-1} \text { ) }\end{array}$ & Paddy yield ( $\mathrm{t} \mathrm{ha}^{-1}$ ) & Harvest index (\%) \\
\hline $\begin{array}{l}2 \% \text { foliar spray of } \mathrm{N} \text { at } \\
\text { tillering }\end{array}$ & $7.3167 \mathrm{ab}$ & $19.497 \mathrm{ab}$ & $9.540 \mathrm{abc}$ & $3.5567 \mathrm{bc}$ & $37.268 \mathrm{ab}$ \\
\hline $\begin{array}{l}2 \% \text { foliar spray of } \mathrm{N} \text { at } \\
\text { booting }\end{array}$ & $7.4833 \mathrm{ab}$ & $19.683 \mathrm{ab}$ & $9.270 \mathrm{bc}$ & $3.4867 \mathrm{bc}$ & $37.662 \mathrm{a}$ \\
\hline $\begin{array}{l}2 \% \text { foliar spray of } \mathrm{N} \text { at } \\
\text { flowering }\end{array}$ & $7.66 \mathrm{a}$ & $19.817 \mathrm{ab}$ & $9.913 \mathrm{ab}$ & $3.6533 \mathrm{ab}$ & $36.836 \mathrm{ab}$ \\
\hline $\begin{array}{l}2 \% \text { foliar spray of } \mathrm{Zn} \\
\text { at tillering }\end{array}$ & $6.81 \mathrm{~b}$ & $18.09 \mathrm{~b}$ & $9.443 \mathrm{bc}$ & $3.4767 \mathrm{bc}$ & $36.810 \mathrm{ab}$ \\
\hline $\begin{array}{l}2 \% \text { foliar spray of } \mathrm{Zn} \\
\text { at booting }\end{array}$ & $7.1900 \mathrm{ab}$ & $18.340 \mathrm{ab}$ & $9.15 \mathrm{c}$ & $3.3200 \mathrm{c}$ & $36.27 \mathrm{~b}$ \\
\hline $\begin{array}{l}\text { 2\% foliar spray of } \mathrm{Zn} \\
\text { at flowering }\end{array}$ & $7.3167 \mathrm{ab}$ & $18.483 \mathrm{ab}$ & $9.477 \mathrm{abc}$ & $3.5333 \mathrm{bc}$ & $37.284 \mathrm{ab}$ \\
\hline $\begin{array}{l}2 \% \text { foliar spray of } \mathrm{N}+ \\
\text { Zn at tillering }\end{array}$ & $7.3567 \mathrm{ab}$ & $19.617 \mathrm{ab}$ & $9.890 \mathrm{ab}$ & $3.7367 \mathrm{ab}$ & $37.79 \mathrm{a}$ \\
\hline $\begin{array}{l}2 \% \text { foliar spray of } \mathrm{N}+ \\
\text { Zn at booting }\end{array}$ & $7.5567 \mathrm{ab}$ & $19.793 \mathrm{ab}$ & $9.803 \mathrm{abc}$ & $3.6967 \mathrm{ab}$ & $37.710 \mathrm{a}$ \\
\hline $\begin{array}{l}\text { 2\% foliar spray of } \mathrm{N}+ \\
\mathrm{Zn} \text { at flowering }\end{array}$ & $7.6133 \mathrm{ab}$ & 20.09 a & $10.12 \mathrm{a}$ & $3.8200 \mathrm{a}$ & $37.755 \mathrm{a}$ \\
\hline LSD $0.05 p$ & 0.8219 & 1.9821 & 0.6677 & 0.2627 & 1.1301 \\
\hline
\end{tabular}

\section{References}

1. Fahad S, S Hussain, S Saud, F Khan, S Hassan et al. (2015) Exogenously applied plant growth regulators affect heat stressed rice pollens. J Agron Crop Sci. 10: 1111.

2. Charalampopoulos D, R Wang, S Pandiella, C Webb (2002) Application of cereals and cereal components in functional foods a review. Int J Food Microbiol 79(1-2): 131-141.

3. Champagne ET, DF Wood, BO Juliano, DB Bechtel (2004) Rice chemistry and technology (No Edn 3). American Association of Cereal Chemists Inc, USA.

4. Esa N, T Ling, L Peng (2013) By products of rice processing: an overview of health benefits and applications. J Rice Res 1:107.

5. Anonymous (2018) Economic Survey of Pakistan. Ministry of Food and Agriculture, Federal Bureau of Statistics Islamabad, Pakistan, pp. 17.

6. Cisse L, B Amar (2000) The importance of Phosphatic fertilizer for increased crop production in developing countries. In: Proceedings of the AFA $6^{\text {th }}$ International Annual conference held on 31 January-2 February 2000, Cairo, Egypt.

7. Samonte SOPB, LT Wilson, JC Medley, SRM Pinson, AMM C-Clung (2006) Nitrogen utilization efficiency: relationships with grain yield, grain protein, and yield-related traits in rice. Agro J 98: 168-176.

8. Mae T, A Inaba, Y Kaneta, S Masaki, M Sasaki et al. (2006) A Large Grain Rice Cultivar, Akita 63 Exhibits High Yields with High Physiological N-Use Efficiency. Field Crops Res 97: 227-237.

9. Rana WK, SR Kashif (2014) Effect of different zinc sources and methods of application on rice yield and nutrients concentration in rice grain and straw. J Environ Agric Sci 1: 9.

10. Yosefi K, M Galavi, M Ramrodi, SR Mousavi (2011) Effect of bio phosphate and chemical phosphorus fertilizer accompanied with micronutrient
$2 \%$ nitrogen and zinc at tillering stage. Minimum harvest index $(36.27 \%)$ was observed with foliar spray of zinc at booting stage. Higher harvest index indicated its superior ability of better dry matter partitioning towards grains [14]. foliar application on growth, yield and yield components of maize (Single Cross 704) Aust J Crop Sci 5(2): 175-180.

11. Alloway BJ (2008) Zinc in soils and crop nutrition. Second edition, published by IZA and IFA, Brussels, Belgium, Paris and France.

12. Outten CE, TV O Halloran (2001) Femtomolar sensitivity of metalloregulatory protein controlling Zn homeostasis. Science. 292: 2488-2492.

13. Pandey N, GC Pathak, CP Sharma (2006) Zinc is critically required for pollen function and fertilisation in lentil. J Trace Elem Med Bio, 20(2): 89-96.

14. Ali M, L Ali, M Sattar, MA Ali (2010) Improvement in wheat (Triticumaestivum L.) yield by manipulating seed rate and row spacing in Vehari zone. J Anim Plant Sci 20: 225-230.

15. Xi Wen Y, L Xiao-Hong, T Xin-Chun, GJ William, C Yu-Xian (2011) Foliar zinc fertilization improves the zinc nutritional value of wheat (Triticum aestivum L) grain Afr J Biotechnol 10 (66): 14778-14785.

16. IRRI (2000) Nutritional disorders and nutrient management in rice. Inter Rice Res Ins Manila, Philippines.

17. Sud YK, RP Arrora, DL Deb (1990) Nitrogen uptake and its utilization in wheat. Ann Agric Res 11: 139.

18. Howard DD, CO Gwathmey (1995) Surfactant effect on potassium uptake by cotton from foliar KNO3 application. J Plant Nutr 18: 2669-2680.

19. Kettlewell PS, JW Cook, DW Parry (2000) Evidence for an osmotic mechanism in the control of powdery mildew disease of wheat by foliar applied potassium chloride. European J Plant Pathol 106(3): 297-300.

20. Gab Alla FI, MA Gomaa, FI ElAraby (2003) Effect of nitrogen fertilizer and some micronutrients as foliar application on wheat. Annals Agric Sci, Ain Shams University 31: 273-289. 
21. Dekov D (2004) Effect of late foliar application of nitrogen on grain yield and quality of soft and durum wheats. Rasteniev dni Nauki 25: 17-23.

22. Steel RGD, JH Torrie, DA Deekey (1997) Principles and procedures of Statistics. A Biometrical Approach. $3^{\text {rd }}$ ed Mc Graw Hill Book. Int Co New York, USA pp. 400-428.

23. Islam MS, MM Akhter, MSQ Rahman, MB Banu, KM Khalequzzaman (2008) Effect of Nitrogen and Number of seedlings hill-1 on the yield and yield components of T. aman rice (BRRI Dhan 33) Int J Sustain. Crop Prod 3:61-65.

24. Abdul SM, S Balasubramanian (1988) Influence of $\mathrm{N}, \mathrm{Zn}$ and their interaction on the yield and nutrient uptake of 'IR20' rice (Oryza sativa) in different seasons. Indian J Agric Sci, 58:190-193.

25. Bandara WMJ, DB Wickrama, DNS Sirisena, LC Silva (2001) Effect of applied $\mathrm{Zn}$ on $\mathrm{N}$ use efficiency, growth and grain yield of rice grown in low humic grey soils of low country intermediate zone. Rice Research and Development Institute, Batalagada, Ibbagamuda.

26. Sarwar M (2011) Effects of Zinc fertilizer application on the incidence of rice stem borers (Scirpophagas pecies) (Lepidoptera: Pyralidae) in rice (Oryza sativa) crop. J Cereals Oilseeds 2: 61-65.
27. Suleimani R (2006) The effects of integrated application of micronutrient on wheat in low organic carbon conditions of alkaline soils of Western Iran. Proceedings of the $18^{\text {th }}$ World Congress of Soil Science, July 9-15, Philadelphia, USA.

28. Ranjbar GH, SAM Cheraghi, M Qadir (2010) Yield response of different wheat genotypes in saline areas of lower karkhehriver basin of Iran Am Euras. J Agric Environ Sci 8(1): 50-54.

29. Chaphale SD, WP Badole (1999) Response of rice (Oryza sativa L) to zinc application. Indian J Agron 44: 539-542.

30. Erdal I, A Yilmaz, S Taban, S Eker, B Torun (2002) Phytic acid and phosphorus concentrations in seeds of wheat cultivars grown with and without zinc fertilization. J Pl Nutri 25(1): 113-127.

31. Hu YX, CG Qu, JN Yu (2003) Zn and Fe fertilizers effects on wheat's output. Chinese Germplasm. 2: 25-28.

32. Genc Y, GK McDonald, RD Graham (2004) Differential expression of zinc efficiency. Pl Soil 263: 273-282.

33. Chen WR, ZL He, HE Yang, Y Feng (2009) Zinc efficiency is correlated with root morphology, ultrastructure and antioxidative enzymes in rice. J Pl Nutri 32: 287-305.

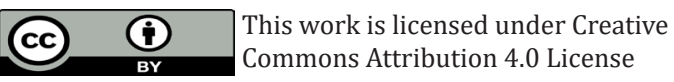

To Submit Your Article Click Here: Submit Article

DOI: $10.32474 /$ CIACR.2018.04.000183

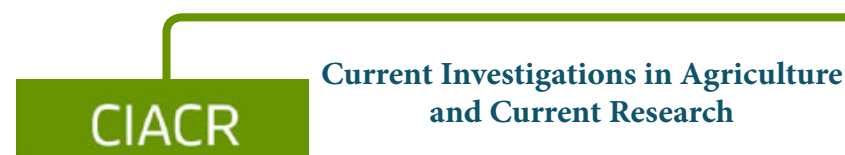

Assets of Publishing with us

- Global archiving of articles

- Immediate, unrestricted online access

- Rigorous Peer Review Process

- Authors Retain Copyrights

- Unique DOI for all articles 